\title{
A Road Map to Nigeria Entrepreneurial Greatness
}

\author{
Frank Alaba Ogedengbe \\ Michael and Cecilia Ibru University \\ Augustine Okoekhian Ekeria \\ Auchi Polytechnic, Nigeria \\ Donald Ozemen Ewanlen \\ Federal University Otuoke
}

This paper considers the processes of mastery of entrepreneurial personality, from childhood to the time of retirement from active entrepreneurial practice. It proffers that underpinning construct for the realization of the envisaged economic expansion is entirely developmental. It posits an agenda of developing the entrepreneur from cradle to grace, which involves active participation of all institutions in the society. It contends that the era of relying solely on natural entrepreneurs for economic development is over. To achieve the desired economy, we must develop indigenous entrepreneurs and equip them. This requires the active involvement of all stakeholders in the Nigeria project.

\section{INTRODUCTION}

The entrepreneur in the context of this paper is the originator or creator of a profit seeking organization established for the purpose of providing goods and services for the consumption of the society. The entrepreneur is often referred to as the agent of economic, technological and social systems (Ogundele and Olayemi, 2004). Entrepreneurship is considered as the processes of emergency, behaviour and performance of entrepreneur (Ogundele, 2004a). The formal processes of equipping the entrepreneur with necessary insight and skill are through formal education, entrepreneurial training and development.

Education is commonly considered as formal process of learning in school, college or university. Udo-Aka (1987) considers education as involving the acquisition of general knowledge and development of basic mental capacity. Therefore, the main burden of education falls upon our formal school system, since education is concerned with increasing general knowledge and understanding of the total environment (Filippo, 1966).

It is to be noted that business firms, religious institutions and other forms of social organisations are equally involved in the educational process. Training is considered as the organised procedure by which people learn knowledge and/or skills for definite purpose (Bench, 1975). The objective of training is to achieve change in behaviour of the trained. Yoder (1963), notes that training means to educate somewhat narrowly, by instruction, drilling, disciple and other methods of modifying behaviour. Learning is another related concept, which is the human process by which skills, knowledge, habits and attitudes are acquired 
and utilized in such a way that behaviour is modified. Thus education as used here is inclusive of training and learning process (Ogundele and Kio, 2002).

Development in the general sense is many sided process. At the individual level; it implies increase skill and capacity, greater freedom, creativity, self-discipline responsibility and material well being (Rodney, 2005). The achievement of any of those aspects of personal development is very much tied with the state of the society of a whole. At the level of social groups development implies an increasing capacity to regulate both internal and external relationship. Rodney, (2005) is of the view that the tool with which men work and the manner in which they organise their labour are important indices of social development. Rodney (2005), notes further that development when used exclusively in economic sense refers to how members of a society increase jointly their capacity for subduing the environment. This capacity is dependent on the extent to which they understand the laws of science and on the extent to which they put technology to use and on the manner in which work is organised. All these are assisted by the processes of formal education, training and development in the society.

At the turn of the $20^{\text {th }}$ century Nigeria in the quest to among the world economic giants convinced The "New Nigeria" approach aimed galvanizing quantum movement of people into entrepreneurial activities. This new agenda consist of sequence activities targeted at sustainable entrepreneur development for a great and dynamic economy in Nigeria. This paper advocates that entrepreneurship development in Nigeria must focus on producing new breeds of entrepreneurs with visions for the future development of the country.

\section{CONCEPTUAL FRAMEWORK}

Development, as noted by Hornby, (1974) is gradual advancement through progressive stages of growth from within. From this point of view development implies 'changes' and this is very important in any consideration of entrepreneurship education and development. From a broader perspective, the development approach to entrepreneurship considers the nurturing of the actual or potential entrepreneurs to become more effective in running their own organisations Singh, (1996), notes that this has to be done at various stages and in various training and development institutions. The development theory developed by Singh, (1986), has its foundation in massive education, training and development of the entrepreneurs from childhood, on the need for achievement motive. Singh, (1986) further notes that entrepreneurial performance is influenced by three factors. First, is his or her attitude towards his/her occupation. Second, the role expectations held by the sanctioning groups. Third factor is the operational requirement of the job. He notes that society's values are most important determinants of the first two factors, education, training and development is crucial for the third.

Ekpo-Ufot (1988) avers that there are seven determinants that affect entrepreneurship response in any nation. These are (1) society's value and need (2) family (3) schools (4) work organisation (5) urbanisation and industrial estates (6) availability of financial resources and (7) government. He states that there are several ways in which determinants can be structured to accelerate entrepreneurship development. We are of the opinion that there is an urgent need for a restructuring of our educational system for a meaningful education and development of entrepreneurs in order to attain economic development in the 21 st century. Okaka, (1990) believes that entrepreneurial success depends on development. This implies that to be successful entrepreneurs need to possess certain qualities in addition to skills and knowledge concerned with the technical aspect of owning a business, such skills are acquired through organised education, training and development. These skills include: (1) Development of entrepreneurial spirit, characteristics and personality (2) Development of technical, technological and professional competencies needed for productive work employment (3) Development of enterprisebuilding and small business development, capabilities to initiate and start one's own business or self employment and (4) Development of managerial capability to run the business and other self employment activity successfully.

Ogundele, (2000) note that the areas covered by the development theory involve both macro and micro level issues. At the macro level it covers training in opportunity awareness, relating to relevant 
publics, technology, market and dealing with government agencies. The micro level issues include entrepreneurial personality in terms of attitudes, motivation, values education, and work experience. The approach emphasizes education, training and development as important determinants in the process of entrepreneurship. The development theory envisages the positive consequences of education, training and development on several determinants that affect entrepreneurs and entrepreneurship activities. The utilization of this approach holds much promise for the under developing countries of Africa.

\section{MODEL OF ENTREPRENEURSHIP DEVELOPMENT FOR NATIONAL DEVELOPMENT}

Here we attempt to paint a picture of how entrepreneurship can result in Nigeria's greatness in the 21 st century. At the micro level, the model focuses on the personality of the individual or entrepreneur. The issues of focus at this level are the fundamental characteristics of the individual. They are based partly on the physical make-up of the individuals and the mental capacity which will set some limits as to the types of the opportunities that could be exploited by them. Others are the individual's attitudes, motivations and needs as a member of a family and the general society. Training and development are expected to positively help in reducing areas of shortcomings which will lead to improved performance in entrepreneurship practice.

The intermediate level relates to supportive institutions and agencies that could further mould the entrepreneurs or individuals, by equipping them with more practically oriented skills and competencies for improve performance. The assumptions here are that existing or practicing entrepreneurs could perform better when exposed to relevant education, training and development and non- entrepreneurs could be developed to become active entrepreneurs or self-employed.

The macro level focuses on the individual's childhood and adolescence environments. The economic characteristics of the individual's environment include the political systems and priorities, technology, culture, religious and social values (Ogundele, 2004b) and (Ogundele and Operifa, 2004). A thorough combination of these macro level variables will help in determining the type of education, to which the individual could be exposed. We are of the opinion that when the these agenda are properly implemented, will lay requisite foundation for educating and developing the torch bearers for national development.

\section{INTERACTIVE MODEL OF SOCIAL-ECONOMIC DEVELOPMENT}

The interactive Model of self-reliant socio-economic development is intended to complement the model on entrepreneurial development with a view to producing technological innovation and result oriented entrepreneurs who have practical training in relevant industrial sectors of the economy. The principal institutions of development are the schools system which depict academic career growth. Workers in the industry will, also ensure that learning and research are made relevant to the needs of this country (Ogundele, 2005a).

The operators include:

1. Existing educational institutions, including universities, polytechnics, vocational and primary schools.

2. Existing business sector of the economy. They will contribute fund to the national Research and Development, which must be compulsory.

3. National, state and local governments will also contribute which will be used to establish $\mathrm{R}$ and D Corporation, with three major division, instructional and scientific equipment activities, and motor vehicle and food processing. The development activities will involve students in formal educational systems, and other forms of training and development on short term basis provided for the general public.

The lesson that we have learnt from the Asian Tigers is that effective entrepreneurial education, training and development are the only sure path to national economic development. Nigeria can trend this 
path through the collaborative and interactive efforts of the educational institutions, the government, industry and other relevant social institutions.

\section{EDUCATION FOR NATIONAL DEVELOPMENT}

Recent developments in South East Asia have already shown other third World countries like Nigeria that a nation's progress and economic development is not essentially constrained by the levels of natural resources it possesses, but by the human capacity and capability in responding to challenges in the environment. The Asia Tigers have developed and equipped their human assets with orientation and capacity for spontaneous responses to opportunities of wide ranging patterns both near and far. Because of appropriate entrepreneurial education, training and development, right from childhood every six out of ten people in Indonesia are entrepreneurs. The truth is that entrepreneurship has become a culture of that country and indeed all the Asian Tigers. That is why their economies are the fastest growing and developing ones in the world today. Consequently, entrepreneurship development has equipped the Asian Tigers with the competencies of turning their economies to very dynamic ones for national development. For Nigeria and other sub-Saharan Africa countries to move into the club of great and dynamic economies, there must be massive an all embracing entrepreneurial training and development program.

\section{ENTREPRENEURSHIP EDUCATION AT THE PRIMARY LEVEL}

The proposed entrepreneurial educational training and development agenda for national development should be aimed achieving the following 1) Installing Training and Development Programs for Entrepreneurial Development 2) Institution of Basic Entrepreneurial Education at Primary School Level. The Educational model of the Living Faith Church Worldwide could be replicated. It must be stated here, that the levels of formal education will affect entrepreneurship (Ogundele, 2000). In addition, the levels and types of technical, vocational, managerial and other forms of specialised education, training and development will equally affect entrepreneurship. The neglect of entrepreneurship education would adversely affect the slow pace of performance of the economy. Therefore, appropriate entrepreneurial educational training and development programmes must be provided for pupils and students of various levels of Nigeria educational systems and for the adult in other forms of social institutions of which they are members.

In this era, it is not enough to teach pupils the skills of reading, writing, calculating and elementary science at the primary level. They must be taught how to apply these skills in solving the problems of society. They must be taught to develop vision of a better future society, thus making infants to be visionary conscious. They must be initiated into intuitive sensitivity of seeing order in disorder through practice and deep listening. The young ones must be educated on self awareness and risk tasking confidence, which are part of the need for achievement. Based on the challenges of globalisation our pupils should be educated to develop the skill of multicultural responsive that is analyzing different culture to know more about the world of others and how they could be exploited. They must also be introduced to the various occupational areas in their local environment. The aforementioned implies that they become pathfinders in developing great and dynamic economy. Therefore, entrepreneurial educations have to be provided to pupils and teachers at the primary level.

\section{ENTREPRENEURIAL EDUCATION AT THE SECONDARY SCHOOL LEVEL}

If the 6-3-3-4 educational policy in Nigeria is made functional there should be little problems in building on the foundations which have been laid at the primary schools level. There are serious defects in the provision of facilities, equipments and personnel at the primary school level. The implementation of the 3-3 educational programs at the secondary school level is a must for producing students who will be agents for national development in the 21 st century. During the first three years teachers at the secondary school level will have to build on, and further develop the skills of intuitive sensitivity, self awareness, 
risk taking, visionary consciousness and multinational responsiveness whose foundations should have been laid at the primary school level, at secondary level the last three years of the students will focus efforts in areas where they have exhibited the best competences to contribute most to the social development.

Those who are not best suited for pure academic pursuit would at this level branch out into relevant vocational area for them. They will immediately become agents in the process of producing the desired great patterns of national development. They will be expected to be actively involved in the practical implementation of model 2 of this paper. Again at this level entrepreneurial education have to be provided for both the trainees and the trainers.

\section{ENTREPRENEURIAL EDUCATION AT THE TERTIARY EDUCATION LEVELS}

This level includes the colleges of education, the polytechnics, the Universities at graduate and post graduate levels and other forms of private initiatives designed to promote entrepreneurship. It is to be noted that presently, there are some forms of entrepreneurship education and development at the tertiary educational levels. In some institutions it is taught only in one semester out of eight in four years of a student's academic experience with varying course contents. Some institutions are even planning to provide their students with facilities and fund to practice their pet ideas. The best practice will be to ensure that students take at least a course in entrepreneurship in every year of their academic pursuit at the tertiary educational level, under varying titles such as entrepreneurship development, small business management, management of small scale industry, managing your own business, etc. The implementation of model 2 is particularly relevant at this level. Ogundele, (2004a) notes that to produce effective entrepreneurs, the education training and development programs at this level should be of three broad approaches, namely; functional, behavioural and environmental.

The functional approach will equip the practicing and would be entrepreneurs with, planning, initiating, controlling, supporting, information, evolution, development of technical, enterprise building and managerial skills. The behavioural approach will focus on building appropriate entrepreneurial attitudes, values, beliefs, norms, customs, perception, motives and needs. It is environment of the entrepreneurs' spirit, characteristics and personality. The environmental aspect refers to the external environment in figure 1 above; the impetus at this level has to be provided by others. These include the family environment, social and religious groups, formal educational systems, government agencies and private initiatives, the legal and political framework, available technology and cultural system. All of these must act as facilitators for entrepreneurial practice.

In addition, there must be provision of necessary financial assistance and conducive rural and urban environments, for nurturing and supporting entrepreneurship (Ogujiuba, Ohuche and Adenuga, 2004). These will lead to the development of entrepreneurs who will be agents in spearheading national development economy.

\section{ENTREPRENEURIAL DEVELOPMENT OF THE MASSES}

The widespread level of unemployment in the country could have been minimized if Nigerians of varying age groups and backgrounds were exposed to entrepreneurial education, training and development across levels. The quest for producing great and dynamic economy, in the 21 st century, if Nigeria is not to be left behind the rest of the world in the match towards propensity demands that all hands must be utilised to provide entrepreneurial education training and development for the general populace. The evangelistic agenda will not be complete if any segment of the society is not catered for. Everybody must be an entrepreneurial crusader from the urban to rural areas. This will be in our community centres, in the urban and rural areas, through special programs by the churches and mosques designed for installing entrepreneurial spirit in the individuals. At specified schools, adult education programs at convenient times should be put in place to have all round entrepreneurial education and 
development programs for Nigerians. This means that there must be entrepreneurial evangelism. This also calls for large number of trainers for these programs.

\section{ENTREPRENEURIAL SKILLS FOR THE 21ST CENTURY NATIONAL DEVELOPMENT}

The demands of globalization have shown that Nigeria entrepreneurs must have multiples skills if they are to be agents of national development. Ogundele, (2005a) presents three broad categories of such skills which have twenty eight elements. The first is Management Development Perspective Skills. There are thirteen elements in this category, they are; time managements, entrepreneurial self development, managing change for competitive success; decision-making, human resources environment of business; helping people to learn; team building; project management, re-engineering or business process redesign; total quality management, organizational development, corporate excellence and people skills.

The second is Interpersonal Skills. There are also twelve elements in this group, they include; leadership; subordinate development, delegation and counseling, information technology, re-engineering entrepreneurship ventures, managing information, employee empowerment, conflict management, negotiating, and communication skills.

The third category is cross-sectional skills. This group consists of four elements which are innovation/creativeness, planning, organizing and Kaizen skills.

Other areas where skills development are needed by Nigerian entrepreneurs are in cultural adaptation, managing knowledge for organization success, creating participative organization, quality customer service, managing employees health, physical, mental job specifics, technical transfer of knowledge and human relations skills.

These skills must be developed in Nigerian entrepreneurs in other to be capable to effectively confront the challenges of globalization and other environmental factors, which will ultimately culminate into national prosperity. It is our belief that the adaptation and implementation of the aforementioned programs could take the Nigeria project a step forward towards laying a solid foundation for rapid national development in the 21 st century.

\section{ROAD MAP TO GREATNESS}

We wish to enumerate some strategies that could be implemented to launch Nigeria into an Entrepreneurial giant she truly deserves.

1. A commonly accepted slogan on the dignity of either owing a part time or full time business propagated in all Nigerian languages should be put in place.

2. The mass media should be actively involved in mobilizing the masses for effective participation in entrepreneurial activities to promote national development.

3. There should be a reduction in the high wages paid politicians as it serves as a disincentive to entrepreneurial initiatives among the growing army of unemployed graduates.

4. Government should create a special fund to assist unemployed graduate entrepreneurs before their ventures begin to yield returns.

5. Present and potential entrepreneurs should positively embrace Electronic commerce so as to take advantage of globalization and its attendant competition just like other developed economies.

6. The government at various levels should take advantage of the numerical strength of women and their easy of adaptation as special agent in the quest for inculcating the culture of ownership of small businesses in Nigeria.

7. Entrepreneurs succession problems can be minimized by bridging the gap between aging/ retiring entrepreneurs and their young successors.

8. Government should put up a concerted effect on even infrastructural development at local, state and federal levels. 
9. There should be an emergence of socially and morally conscious entrepreneurs championing the crusade against unethical business actions on the part of beneficiaries from the proposed entrepreneurial development agenda.

\section{CONCLUSION}

It is the contention of this paper that any nation that initiates a program that encourages her citizens to embrace skill acquisition and entrepreneurial development is on the pathway to greatness. We are also of the opinion that massive entrepreneurial education, training and development, right from childhood and continuous until one retires from gainful employment are sine quo non for national prosperity. We are of the opinion that this massive entrepreneurial education be all encompassing devoid of discrimination on the basis of gender, ethnicity and religion. At the primary school level the "catch them young concept" should be the principal focus. At the secondary and tertiary levels students are to be provided with some form of background knowledge on entrepreneurship that should be complemented with industrial experience by the learners. The dynamism in the global environment demands that entrepreneurs should constantly upgrade their skills Special equipped private and government agencies in Nigeria such as.

Administrative Staff College of Nigeria (ASCON) and Centre for Management Development (CMD) in addition to other formal educational institutions have training programs for indigenous entrepreneurs to upgrade their entrepreneurial skills. We advocate that there is the need for an attitudinal re orientation among Nigerians especially towards owing one form of business or the other. This calls for a "people change approach" if we are to have achieve our aspiration of becoming one of the biggest economies in the world.

Governments as well as private organizations' supports are urgently required in order to achieve the desired positive changes. Considering the market size, Nigeria in the $21^{\text {st }}$ century will become the envy of the world when all stakeholders exhibit the will to embrace change, uphold high ethical standard and visionary in leadership. 


\section{REFERENCES}

Abererombie N., Hill S., \& Turnor, B.S. (2000). The penguin Dictionary of Sociology, $4^{\text {th }}$ Ed. London; Penguin Books.

Beach, P.S. (1975). Personnel Management of People at Work, 3rd Ed. New York; Macmillan Publishing Co. Inc.

Ekpo-Ufot, A. (1988). How to Develop the technologically Innovative Entrepreneur and his Planning Skills. Fredreck Ebert Foundation Workshop on entrepreneurship Development in Nigeria, University of Lagos, November 28-30

Flippo, E. (1966). Principles of personnel Management, 2nd Ed. New York. McGraw Hill Book company.

Hornby, A.S. (1974). Oxford Advanced Learner Dictionary of Current English. London Oxford press.

Ogujiuba, K.K., Ohuche, E.K., \& Adenuga, A.O (2004). Credit Availability to Small and Medium Scale enterprise in Nigeria: Importance of New Capital Base for Banks - background and Issues Bullion. CBN, 28(4), 57-68.

Ogundele O.J.K., \& Kio, J.S. (2002). Education, Communication and Behavioural Change in Nigeria and $N E P A D$. 2nd National Conference; Lagos State National Polytechnic, Ikorodu, $9^{\text {th }}$ October.

Ogundele O.J.K. (2000). Determinants of entrepreneurial Emergence, Behaviour and Performance in Nigeria. Unpublished Ph.D Thesis, University of Lagos, Akoka.

Ogundele O.J.K. (2004b). Entrepreneurship Development: Vehicle of people change Approach to SelfActualization and Sustainability. Conference Paper, 10th Annual National Conference, National Association of Curriculum Theorists, Federal College of Education, Asaba, 18th - 22nd October.

Ogundele O.J.K., \& Olayemi, O.O (2002). Entrepreneurial Education and Social economic Reconstruction, Nigeria Journal of curriculum and Instruction, 12, 161-165.

Ogundele O.J.K., \& Opeifa, A.Z (2000, October). The Influence of External Political Environment on the Process of entrepreneurship. The Nigeria Academic Forum: A Multidisciplinary Journal, 5.

Ogundele O.J.K. (2005b). Entrepreneurship development for a Great and Dynamic Economy in Nigeria. 2nd Annual Conference, National Association for Encouraging Quality Education: Ambrose Alli University, Ekpoma, 9th -13 th November.

Ogundele O.J.K. (2004a). Entrepreneurship and Entrepreneurship in Business Organizations, in Ogundele O.J.K (Ed) Introduction to Business Organisation. A Book for Readings 348-365, Lagos, Molofin Nominees. European Scientific Journal March edition vol. 8, No.6 ISSN: 1857 - 7881 (Print) e - ISSN 1857- 7431. 